\title{
Mariusz Sagan
}

\section{Instytucjonalne uwarunkowania funkcjonowania przedsiębiorstw a zrównoważony rozwój}

Streszczenie: Instytucje odgrywają coraz większe znaczenie w tworzeniu polityki zrównoważonego rozwoju, zarówno na szczeblu makro- i mikroekonomicznym. Kształtują zasady związane z funkcjonowaniem przedsiębiorstw, rozwojem społecznym oraz ochroną środowiska. Celem artykułu jest analiza związków pomiędzy wybranymi instytucjonalnymi uwarunkowaniami funkcjonowania firm, a zdolnością przedsiębiorstw do adaptacji/współtworzenia wymogów zrównoważonego rozwoju oraz kreowania swoich strategii biznesowych w oparciu o omawianą koncepcję. Na podstawie prowadzonych rozważań należy stwierdzić, iż proces dostosowywania się biznesu do Agendy 2030 i wyznaczonych celów zrównoważonego rozwoju, ma charakter w zdecydowanej większości adaptacyjnego przyjmowania narzuconego ładu instytucjonalnego: międzynarodowego i krajowego. Proces ten jest rozciągnięty w czasie i charakteryzuje się różną dynamiką, w zależności od stopnia rozwoju systemów społeczno-gospodarczych w poszczególnych krajach i regionach oraz standaryzacji norm międzynarodowych.

Słowa kluczowe: instytucjonalizm, zrównoważony rozwój, przedsiębiorstwo

Institutional determinants of enterprise operation in respect of sustainable development

Summary: Institutions are playing an increasingly important role in creating sustainable development policies, both at the macro and micro level. They shape the rules related to the functioning of enterprises, social development and environmental protection. The aim of this article is to analyze the relationship between selected institutional conditions of company operations and the ability of companies to adapt/co-create the requirements of sustainable development and create their business strategies based on the discussed concept. On the basis of the considerations carried out, it should be stated that the process of adapting business to the Agenda 2030 and the set objectives of sustainable development is largely adaptive in nature, 
adopting the imposed institutional order: international and national. This process is stretched in time and is characterized by different dynamics, depending on the degree of development of socio-economic systems in individual countries and regions and standardization of international standards.

Keywords: institutionalism, sustainable development, enterprise

JEL: D02, F23, L20

\section{Wprowadzenie do problematyki badania}

Instytucje odgrywają obecnie coraz większe znaczenie w tworzeniu polityki zrównoważonego rozwoju, zarówno na szczeblu makro- i mikroekonomicznym. Kształtują i współkształtują m.in. zasady związane z rozwojem społecznym i sprawami socjalnymi, ochroną środowiska, rozwojem indywidualnym jednostek oraz konkurencyjnością przedsiębiorstw. Kluczowym podmiotem w układzie biznes - instytucje, od którego zależy respektowanie zasad zrównoważonego rozwoju, jest jednak samo przedsiębiorstwo.

Zrównoważony rozwój został określony przez Zgromadzenie Ogólne Narodów Zjednoczonych, które przyjęło Agendę Zrównoważonego Rozwoju na rok 2030 oraz zdefiniowało 17 Celów Zrównoważonego Rozwoju (Sustainable Development Goals - SDG), uniwersalnej strategii rozwoju całego świata. Agenda 2030 zobowiązuje społeczność globalną do „osiągnięcia zrównoważonego rozwoju w jej trzech wymiarach - ekonomicznym, społecznym i środowiskowym - w sposób zbalansowany i zintegrowany”. Podkreśla się konieczność integracji wymiaru ekonomicznego, społecznego i środowiskowego, jako klucz do osiągnięcia zrównoważonego rozwoju globu (Integrating, 2015, s. 6). W Agendzie wymienia się trzy wymiary zrównoważonego rozwoju (Transforming, 2015, s. 1-35).

Równość i solidarność społeczna: równość szans dla ludzi, obejmująca dobrobyt, jakość życia i zrównoważony rozwój społeczny - rozwój powinien wyzwalać indywidualne zdolności i zaspokajać ludzkie potrzeby, a tym samym kłaść kres ubóstwu i poprawiać jakość życia jednostek, oferując w dłuższej perspektywie bezpieczne życie z pełnią praw i swobód - oraz spójność społeczną.

Odpowiedzialność za środowisko: zdolność do wykorzystywania zasobów naturalnych bez naruszania równowagi i integralności ekosystemów, zmniejszanie obciążenia środowiska.

Efektywność ekonomiczna: efektywność działań gospodarczych i technologicznych, wspieranie inwestycji i wydajności, wzrost gospodarczy, dbanie o potencjał produkcji gospodarczej.

Koncepcja zrównoważonego rozwoju, aczkolwiek jest również użyteczna jako narzędzie analityczne i polityki publicznej, zawiera inne strategiczne aspekty, takie jak specyfika kulturowa społeczeństwa, instytucje polityczne lub uczestnictwo demokratyczne. Co więcej, musi być ona konceptualizowana w świecie, który przechodzi proces globalizacji i który został głęboko przewartościowany przez zmiany gospodarcze, polityczne, społeczne i technologiczne, które charakteryzowały ostatnie trzydzieści lat. W ramach holistycznej wizji rozwoju, zrównoważony rozwój jest równowagą wszystkich jego wymiarów: środowiskowego, społecznego i gospodarczego, co oznacza przyjęcie podejścia interdyscyplinarnego, charakteryzującego się dialogiem między naukami technicznymi, przyrodniczymi i społecznymi, jak 
również interakcją sektorową między organami publicznymi, osobami prywatnymi i organizacjami społeczeństwa obywatelskiego. W wielu przypadkach, różne zainteresowane strony mają odmienne rozumienie zrównoważonego rozwoju w zależności od ich własnych szczególnych interesów i ideologii, a zatem cele każdego z tych wymiarów mogą być sprzeczne w pewnych obszarach. Z punktu widzenia biznesowego i patrząc na ten problem ze strony przedsiębiorstw, warto podkreślić, iż wśród celów zrównoważonego rozwoju mieszczą się kluczowe wymiary skutecznego i efektywnego biznesu na poziomie mikroekonomicznym, jak też mechanizmy osiągania dobrobytu i jego maksymalizacji w makroskali. Tym samym możemy przyjąć, iż efektywność ekonomiczna jest zarówno celem samym w sobie (elementem zrównoważonego rozwoju), jak też środkiem prowadzącym do uzyskania tego celu.

$\mathrm{Z}$ punktu widzenia interesów przedsiębiorstw, respektowanie zintegrowanych wymiarów zrównoważonego rozwoju ma sens, jeśli przyczynia się to do budowy wartości przedsiębiorstwa i poprawy jego reputacji na rynku, zarówno lokalnym jak też krajowym czy międzynarodowym. Z drugiej strony, biznes funkcjonuje w ściśle narzuconym środowisku instytucjonalnym, którego zadaniem jest m.in. korygowanie niedoskonałości mechanizmów rynkowych, regulowanie odpowiedzialności za środowisko i kwestie społeczne, czy też racjonalizowanie gospodarowania ograniczonymi zasobami. Uwarunkowania instytucjonalne wydają się zatem być jednymi z kluczowych dla funkcjonowania biznesu w respektowaniu wymogów zrównoważonego rozwoju, być może także dla wyborów przez firmy adekwatnych strategii postępowania na rynku: korzystania z zasobów zewnętrznych i przerzucania części kosztów na partnerów biznesowych, czy też bazowania na zasobach własnych. Ten ostatni problem z punktu widzenia badań naukowych nie został jeszcze wystarczająco dobrze zbadany.

Instytucje, jako formalne prawa i nieformalne normy, kształtują i ograniczają decyzje gospodarcze. Każda próba zaimplementowania koncepcji zrównoważonego rozwoju będzie wymagała zatem zmiany ładu instytucjonalnego, który wcześniej nie stymulował w wystarczającym stopniu prospołecznych czy też prośrodowiskowych strategii przedsiębiorstw (Mueller, Mueller, 2011). Co więcej, potencjał takiej zmiany zależy od systemu prawnego i politycznego danego kraju, czyli bardzo ważnych jego instytucji. Państwa, z dobrze funkcjonującymi sądami i innymi instytucjami chroniącymi wymianę gospodarczą, będą mogły łatwiej narzucić model zrównoważonego rozwoju niż w przypadku mniej rozwiniętych systemów politycznych. Skuteczność takiego systemu instytucjonalnego dla wdrożenia zintegrowanego modelu zrównoważonego rozwoju będzie także większa, jeśli nowe polityki oraz proponowane instrumenty będą spójne z dotychczas funkcjonującymi instytucjami, co da następnie większą sprawczość całemu systemowi (Mueller, Mueller, 2011). Do największych wyzwań, związanych na przykład z wdrażaniem środowiskowego wymiaru zrównoważonego rozwoju, zalicza się m.in.: nieodwracalność i skumulowane skutki zmian środowiskowych, złożoność procesów i ich poziom skomplikowania, bardzo duże ryzyko i niepewność, słabo rozwinięte polityki publiczne państwa oraz prawa własności czy też niedoskonałe narzędzia wyceny ekonomicznej zasobów naturalnych. Co więcej, problemy te mają charakter „systemowy”, umiejscowiony głęboko we wzorcach produkcji i konsumpcji, rachunku ekonomicznym i modelach zarządzania. W związku z powyższym, w ostatnim czasie kwestie instytucjonalne zostały włączone również do dyskursu na temat „zarządzania na rzecz zrównoważonego rozwoju”, ponieważ w rzeczywistości instytucje i zarządzanie to częściowo pokrywające się kategorie. Jednak kategorie analityczne instytucjonalizmu są nadal dość różne i inaczej definiowane. Przykładowo, kultura 
i systemy wartości są częściej pomijane w teorii zarządzania, mimo że to kluczowe ograniczenie dla modyfikacji mechanizmów i restrukturyzacji organizacji w imię zrównoważonego rozwoju (Institutions, 2020). Fundamentalne znaczenie dla sprostania temu wyzwaniu ma tworzenie takich podejść do podejmowania decyzji, które cechują się sprawczością w obliczu występującego zawsze ryzyka i niepewności (Handmer, Dovers, 1996, s. 482). Redukcja ryzyka przez otoczenie instytucjonalne (zarówno formalne jak też nieformalne) sprawi, iż wzrośnie gotowość do akceptacji przez biznes rozwiązań promujących zrównoważony rozwój jako element strategii przedsiębiorstwa lub/i jego modelu biznesowego.

Wreszcie, analizując interakcje instytucje - biznes - zrównoważony rozwój w wielowymiarowym otoczeniu społeczno-gospodarczym, nie można zapomnieć o instytucjonalnych wskaźnikach opisujących wspomniany system (i jego podsystemy). Złożone, nieliniowe interakcje instytucji ze sobą i z innymi wymiarami, niemożność pełnego zoperacjonalizowania ich wszystkich, a także fakt, że ten sam efekt (na przykład społeczny lub środowiskowy) może być wywołany przez bardzo zróżnicowane otoczenie instytucjonalne, sprawiają, że wszelkie próby testowania trwałości systemu instytucjonalnego i uzyskiwania wskaźników opartych na uproszczonych, opartych na przyczynowości systemach analitycznych stają się nieprecyzyjne, bądź w ogóle bezzasadne (Towards, 2019). Zamiast tego, jak sugerują liczni autorzy, należałoby wyprowadzić wskaźniki dla systemu instytucjonalnego jako całości, oparte na wyraźnych lub domyślnych celach, a także jasno sprecyzowanych zadaniach modelu zrównoważonego rozwoju i mające na celu pomiar skuteczności systemu instytucjonalnego w ich realizacji. Przykładowo, do takich wskaźników można byłoby zaliczyć udział wydatków sektora $\mathrm{B}+\mathrm{R}$ oraz sektora prywatnego w wydatkach ogółem na zrównoważony rozwój, odsetek wydatków na działania prośrodowiskowe i rozwój społeczny w PKB i inne (Towards, 2019).

Ostatnim elementem analizy w niniejszej części artykułu, jest kwestia skuteczności instytucji w realizacji modelu zrównoważonego rozwoju. Jak już zaznaczono wcześniej, ważnym czynnikiem determinującym skuteczność systemu instytucjonalnego w tym kontekście jest dojrzałość systemu politycznego i prawnego, zakres integracji wewnętrznej stosowanych rozwiązań czy też właściwe owskaźnikowanie procesu. To wszystko wymaga także dużej gotowości systemu do przejścia do nowego modelu zarządzania zrównoważonym rozwojem, co wymaga wielu reform politycznych i instytucjonalnych. Według australijskich autorów, owa instytucjonalna zmiana powinna obejmować następujące formy przejścia (Dovers, River, 2012):

- od krótkoterminowych interwencji w zakresie zarządzania w poszczególnych miejscach do zintegrowanych systemów zarządzania łączących te interwencje w czasie i przestrzeni;

- od krótkoterminowych i wąskich instrumentów i programów politycznych do poprawy zdolności i jakości podstawowych procesów politycznych;

- od marginalnych zmian organizacyjnych do kompleksowej reformy systemu instytucjonalnego;

- od udziału mieszkańców poprzez krótkoterminowe programy o niewielkim poziomie zdecentralizowania do długoterminowych programów i zobowiązań w zakresie na przykład ochrony zasobów;

- od przetasowania instytucji i struktur rządowych (w dotychczasowym modelu top down) do nowych form zarządzania napędzanych przez prawdziwe partnerstwo między nauką, rządem i społecznością (model bootom up). 
Zaprezentowane powyżej rozważania świadczą, iż problem jest wielowątkowy i wielowymiarowy. Większość opracowań w tym obszarze ma charakter ekspertyz, bądź analiz lub artykułów naukowych konceptualno-przeglądowych. W literaturze przedmiotu brakuje uszczegółowionych analiz oraz badań empirycznych, które prezentowałyby wpływ poszczególnych elementów systemu instytucjonalnego na określone składowe trzech wymiarów zrównoważonego rozwoju: ekonomicznego, społecznego i środowiskowego. Pozostając przy tym problemie naukowym, warto także zarysować problematykę zrównoważonego rozwoju i jego instytucjonalnych uwarunkowań dla firm bazujących na zasobach, w porównaniu do przedsiębiorstw z modelami biznesowymi opartymi na dostępie do zasobów. W tym przypadku brak jest jakichkolwiek badań w światowej literaturze przedmiotu, zatem wskazane jest podjęcie prób konceptualizacji tego zjawiska i tych interakcji.

W związku z powyższym, uzasadnione jest podjęcie rozważań konceptualno-teoretycznych, których szczegółowe cele został postawione poniżej.

Celem artykułu jest wieloaspektowa konceptualno-teoretyczna analiza związków pomiędzy wybranymi instytucjonalnymi uwarunkowaniami funkcjonowania firm, a zdolnością przedsiębiorstw do adaptacji/współtworzenia wymogów zrównoważonego rozwoju oraz kreowania swoich strategii biznesowych w oparciu o omawianą koncepcję, $\mathrm{z}$ uwzględnieniem w analizie firm bazujących na zasobach w porównaniu do firm bazujących na dostępie do zasobów. W artykule podjęto próbę wstępnej odpowiedzi na następujące pytania badawcze:

1. W jakim zakresie decyzje przedsiębiorstw, odnośnie wpisania respektowania wymogów zrównoważonego rozwoju do strategii działania firmy, są wymuszone koniecznością dostosowania się organizacji do otoczenia instytucjonalnego, a na ile inne przyczyny mają wpływ na powyższe wybory strategiczne i operacyjne? W jaki sposób instytucje kształtują zachowania przedsiębiorstw w zakresie wybranych wymiarów zrównoważonego rozwoju? Które z uwarunkowań instytucjonalnych mają największy wpływ na respektowanie przez przedsiębiorstwo wymogów zrównoważonego rozwoju?

2. W jaki sposób instytucje kształtują zachowania przedsiębiorstw dla swoich trzech płaszczyzn taksonomicznych: poziomu międzynarodowego, krajowego i regionalnego/lokalnego?

3. Czy organizacje oparte jedynie na dostępie do zasobów zewnętrznych przerzucają obciążenia środowiskowe i społeczne oraz koszty transakcyjne na inne przedsiębiorstwa? Czy instytucje formalne i nieformalne ograniczają takie praktyki/zapobiegają takim praktykom?

\section{Znaczenie instytucji na poszczególnych poziomach taksonomicznych dla zrównoważonego rozwoju}

Ze względu na złożoność i długi horyzont czasowy, zrównoważony rozwój potrzebuje takiej polityki i modeli zarządzania, które są prowadzone na różnych poziomach: lokalnym, regionalnym, krajowym, a także przez instytucje związane z regionalnymi procesami integracji (na przykład Unia Europejska), kończąc na instytucjach międzynarodowych oraz w ramach inicjatyw podejmowanych w ramach globalnej koordynacji przez instytucje do tego powołane. Ład instytucjonalny tworzony na różnych poziomach taksonomicznych oddziałuje bezpośrednio na decyzje przedsiębiorstw odnośnie ich strategii - w związku z paradygmatem zrównoważonego rozwoju. W toczącej się dyskusji podkreśla się, iż rozwiązania instytucjonalne na szczeblu lokalnym i narodowym nie zawsze są kompleksowe i wystarczające, zatem wydaje się, że sku- 
teczność działań w zakresie zrównoważonego rozwoju można by zwiększyć poprzez ustanowienie i wzmocnienie instytucji międzynarodowych na różnych szczeblach władzy i na szczeblu globalnym, aby wspierać budowanie konsensusu, zaangażowanie i partnerstwo, sprawiedliwe procesy i przejrzystość. Rola takich instytucji jest nie do przecenienia (Bochańczyk-Kupka, Pęciak, 2015, s. 34). W tablicy 1 zaprezentowano przykładowy schemat architektury instytucjonalnej na rzecz zrównoważonego rozwoju na różnych poziomach taksonomicznych.

\section{Tablica 1 Bazowy międzynarodowy ład instytucjonalny dla zrównoważonego rozwoju}

\begin{tabular}{|c|c|c|c|}
\hline Instytucje & $\begin{array}{l}\text { Elementy ładu } \\
\text { instytucjonalnego }\end{array}$ & \multicolumn{2}{|c|}{$\begin{array}{l}\text { Poziom zarządczy/poziom taksonomiczny } \\
\text { - przykłady instytucji }\end{array}$} \\
\hline \multirow{3}{*}{ Organizacje } & \multirow{3}{*}{$\begin{array}{l}\text { instytucje międzynarodowe } \\
\text { i organizacje międzyrządowe, } \\
\text { aktorzy polityczni: rządy } \\
\text { państw, NGO’s, związki, } \\
\text { stowarzyszenia }\end{array}$} & globalny & ONZ, UNDP \\
\hline & & ponadnarodowy & $\begin{array}{l}\text { Europejska Sieć na rzecz } \\
\text { Zrównoważonego Rozwoju }\end{array}$ \\
\hline & & krajowy & ministerstwa klimatu \\
\hline \multirow{3}{*}{$\begin{array}{l}\text { Mechanizmy } \\
\text { instytucjonalne }\end{array}$} & \multirow{3}{*}{$\begin{array}{l}\text { formalne systemy } \\
\text { sprawowania władzy: zasady } \\
\text { konstytucyjne, zasady } \\
\text { organizacyjne, pisemne } \\
\text { porozumienia i inne. }\end{array}$} & globalny & $\begin{array}{l}\text { Agenda 21, Agenda 2030, } \\
\text { Deklaracja Sztokholmska }\end{array}$ \\
\hline & & ponadnarodowy & $\begin{array}{l}\text { Europejska Strategia } \\
\text { Zrównoważonego Rozwoju }\end{array}$ \\
\hline & & krajowy & $\begin{array}{l}\text { Krajowe Strategie } \\
\text { Zrównoważonego Rozwoju }\end{array}$ \\
\hline $\begin{array}{l}\text { Orientacja } \\
\text { instytucjonalna }\end{array}$ & $\begin{array}{l}\text { zasady nieformalne: kultura, } \\
\text { religia, wartości, zwyczaje }\end{array}$ & $\begin{array}{l}\text { ponadnarodowy, } \\
\text { krajowy, lokalny }\end{array}$ & $\begin{array}{l}\text { informacja, edukacja, liderzy } \\
\text { opinii, liderzy, normy, } \\
\text { przekonania, rola rodziny }\end{array}$ \\
\hline
\end{tabular}

Źródło: D. Bochańczyk-Kupka, R. Pęciak, op. cit., s. 35.

Agenda Zrównoważonego Rozwoju na rok 2030 wyraźnie wskazuje na kluczowe znaczenie budowy wsparcia instytucjonalnego na każdym z analizowanych wymiarów taksonomicznych. Na poziomie narodowym Agenda 2030 zachęca wszystkie państwa członkowskie do jak najszybszego opracowania ambitnych rozwiązań krajowych, wspierających przejście do realizacji celów zrównoważonego rozwoju i oparciu się na istniejących instrumentach planowania, takich jak krajowe strategie rozwoju i zrównoważonego rozwoju (implementacja SDG do istniejących krajowych systemów planowania strategicznego). Z kolei na poziomie subregionalnym (na przykład UE), powinny zostać ukierunkowane na możliwości partnerskiego uczenia się, w tym poprzez wymianę najlepszych praktyk między regionami i dyskusję na temat wspólnych celów, w ramach prac formalnych i nieformalnych komisji i organizacji (Transforming, 2015, s. 32-35).

Wspomniane zalecenia Agendy 2030 korespondują również z problemami wdrażania nowego ładu instytucjonalnego na poszczególnych szczeblach polityk publicznych: globalnym, subregionalnym, krajowym i lokalnym. Zaleca się, aby stosować zunifikowane etapowe metody stworzone przez OECD, w celu rozwiązywania pojawiających się problemów instytucjonalnych, w implementacji i realizacji założeń SDG. O ile same formalne zmiany instytucjonalne podlegają mniejszej lub większej proceduralizacji, o tyle spore wyzwania pojawiają się przy inicjowaniu zmian dla instytucji nieformalnych, zachodzących w znacznie dłuższych okresach czasu i będących zdecydowanie mniej sterowalne (Spangenberg, 2002, 137-139). 


\section{Respektowanie zrównoważonego rozwoju - perspektywa i zaangażowanie instytucjonalne przedsiębiorstw}

Instytucje tworzą ramy działania dla systemów społeczno-ekonomicznych, w tym dla przedsiębiorstw. Biznes musi przystosować się do obowiązujących regulacji na rzecz zrównoważonego rozwoju, przy czym zakres i tempo procesów dostosowawczych zależy od kontekstu, przejrzystości reguł instytucjonalnych oraz jakości systemów informacyjnych i samej informacji o tym nowym paradygmacie. Firmy włączają się w obowiązujący ład instytucjonalny na rzecz zrównoważonego rozwoju, dla wszystkim trzech wymiarów Agendy 2030: na rzecz zrównoważonego społeczeństwa, gospodarki i organizacji oraz środowiska. Jednocześnie podejmują próby współkształtowania instytucji, poprzez różne modele zaangażowania instytucjonalnego. Styki instytucji i biznesu na rzecz osiągania SDG dla poszczególnych filarów Agendy 2030 mogą dotyczyć następujących ich komponentów:

Zrównoważone społeczeństwo - bezpieczeństwo socjalne (systemy, zasady), zdrowie publiczne (system, zasady), integracja społeczna (mechanizmy), równość płci, sprawiedliwość społeczna, wolność osobista, udział w działalności politycznej i społecznej, możliwość wyboru indywidualnej ścieżki rozwoju (Institutions, 2020).

Zrównoważony wymiar ekonomiczny/środowiskowy - efektywność technologiczna organizacji, efektywność zarządcza, efektywność w zakresie korzystania z zasobów w organizacji, w tym zasobów naturalnych, rozwój kompetencji pracowników, sprawiedliwe wynagradzanie.

Poszczególne kraje na świecie stoją przed szeregiem wspólnych wyzwań w zakresie przygotowania, wdrażania i przeglądu swoich krajowych strategii zrównoważonego rozwoju. Odnoszą się one do przyjęcia odpowiednich strategii instytucjonalnych i ustaleń proceduralnych, tworzących poczucie odpowiedzialności grup docelowych, zapewniających współpracę międzynarodową, właściwy dobór priorytetów, formułowanie spójnej wizji oraz uzgodnienie ścieżki długofalowego rozwoju. Włączanie się przedsiębiorstw w działania zarządcze na rzecz osiągania zrównoważonego rozwoju ma często intuicyjny i eksperymentalny charakter, przy potrzebie zaistnienia silnego komponentu monitoringu, przepływu informacji, w tym zwłaszcza informacji zwrotnych, aby umożliwić organizacyjne uczenie się i doskonalenie (Dovers, River, 2012). Najczęściej stosowaną strategią w tym zakresie jest strategia adaptacyjna do nowo tworzonych i wdrażanych rozwiązań instytucjonalnych zrównoważonego rozwoju, co klasyfikuje ją do modelu instytucjonalnej adaptacji (jako jednego z trzech wymiarów modelu zaangażowania instytucjonalnego) (Sagan, 2016, s. 31-32).

Należy podkreślić, iż respektowanie perspektywy zrównoważonego rozwoju przez biznes ma miejsce częściej, jeśli lokalne władze są wyposażone w narzędzia do koordynacji polityki zarówno państwa, jak też regionu na swoim terytorium. Samorządy lokalne są zobligowane do integracji polityki ochrony środowiska z planowaniem przestrzennym, przepisami BHP w miejscu pracy, wymogami w zakresie zarządzania odpadami oraz szeregiem innych obszarów ważnych dla środowiska. Poszczególne agencje rządowe zwykle zajmują się tylko jedną z tych kwestii, natomiast samorządy są zwornikiem skuteczności wdrażania tych rozwiązań przez przedsiębiorstwa. Rozwiązania zrównoważonego rozwoju są także częściej wdrażane przez biznes, jeśli towarzyszy im zaangażowanie lokalnych interesariuszy, np. IOB i trzeci sektor.

Jednym z kluczowych narzędzi oddziaływania instytucji na biznes (bezpośrednio bądź pośrednio) w kontekście wdrażania zasad zrównoważonego rozwoju, są narzędzia informacyjne, 
w tym dzielenie się wiedzą i dobrymi praktykami. Przykłady ze świata wskazują, iż przedsiębiorstwa osadzone we właściwym kontekście informacyjnym, szybciej i częściej stosują przynajmniej wybrane mechanizmy prośrodowiskowe oraz prospołeczne i realizują cele SDG. Pierwszym ze skutecznych narzędzi instytucjonalnych są praktyki wymiany wiedzy pomiędzy partnerami poprzez wspólną ocenę przedstawionych rozwiązań (peer review). Wzajemna ocena powinna angażować urzędników, biznes i zainteresowane strony z innych państw członkowskich oraz, w stosownych przypadkach, międzynarodowych obserwatorów. Wspólna ocena powinna koncentrować się albo na strategii jako całości, albo na konkretnych tematach, powinna ona również służyć do określenia przykładów dobrej polityki i praktyk. Wskazane jest, aby wzajemne oceny mogły być poparte dowodami naukowymi (National, 2012, s. 22). Jednym z wymiarów z omawianego powyżej narzędzia mogą być także wspólne działania lokalnych samorządów, działających w międzynarodowych sieciach współpracy. Powszechność takich form tworzenia i dzielenia się wiedzą nie dotyczy tylko samych władz lokalnych i ich problemów. W ramach mechanizmów współpracy lokalnych samorządów i lokalnego biznesu, działającego w ramach ekosystemów i klastrów, następuje przekazywanie wiedzy do przedsiębiorstw, m.in. o tym, jakie są dobre praktyki w zakresie wdrażania celów zrównoważonego rozwoju w różnych firmach na całym świecie.

Innym skutecznym narzędziem proliferacji dla środowiska biznesowego informacji o sposobach osiągania celów zrównoważonego rozwoju są normy, w tym normy ISO. Normy opracowane przez Międzynarodową Organizację Normalizacyjną (ISO) są zasadniczo me-

\section{Tablica 2 Przykładowe normy ISO związane z koncepcją zrównoważonego rozwoju}

Standard ISO

ISO $26000 \quad \begin{aligned} & \text { Odpowiedzialność } \\ & \text { społeczna }\end{aligned}$

Rodzina ISO 14000 z 28 normami, w tym ISO $14001 \mathrm{w}$ zakresie zarządzania środowiskowego (EMS), normy dotyczące analizy cyklu życia, etykietowania środowiskowego oraz gazów cieplarnianych (ISO14064:2006 \& ISO14065:2007).

Od normy ISO 9001 do ISO 14001, poprzez inne standardy dotyczące poszczególnych sektorów i problemów.

rozwoju
Odpowiedzialność za środowisko
Efektywność biznesowa, zarządcza/ ekonomiczna

\section{Wymiar}

zrównoważonego Opis przykładu

Opracowany przy zaangażowaniu ekspertów z 99 krajów, w większości z gospodarek rozwijających się i ponad 40 organizacji międzynarodowych. ISO 26000 zawiera wytyczne dotyczące odpowiedzialności społecznej i umożliwia organizacjom biznesowym osiąganie pozytywnych wyników we wszystkich trzech wymiarach zrównoważonego rozwoju środowiskowym, ekonomicznym i społecznym.

Rodzina norm ISO 14000 zapewnia ramy standaryzacji dla organizacji biznesowych, dla wszystkich sektorów gospodarki, w tym sektora publicznego. Ich celem jest minimalizacja szkodliwego wpływu na środowisko naturalne oraz poprawa wyników biznesowych poprzez bardziej efektywne wykorzystanie zasobów.
Standardy zarządzania są szeroko stosowane w celu ustanowienia zaufania pomiędzy partnerami biznesowymi, zwłaszcza w zakresie funkcjonowania globalnych łańcuchów dostaw czy zamówień publicznych (np. normy bezpieczeństwa żywności - ISO 22000).

Źródło: National Institutions for Sustainable Development. A preliminary review of the institutional literature, United Nations Department of Economic and Social Affairs, October 2012, s. 23. 
chanizmami na rzecz wymiany najlepszych praktyk, w oparciu o sieć krajowych instytutów normalizacyjnych ze 163 krajów oraz wiedzę specjalistyczną zarówno z sektora publicznego jak i prywatnego. Przedsiębiorstwa współtworzą zatem w tym przypadku nowe rozwiązania instytucjonalne, co jest przykładem instytucjonalnej wspólewolucji, jako formy zaangażowania instytucjonalnego przedsiębiorstw. Nowe standardy są publikowane lub opracowywane w celu rozwiązywania trudnych kwestii, takich jak odpowiedzialność społeczna, bezpieczeństwo, reagowanie na zmiany klimatu, efektywność energetyczna i zasoby odnawialne, zrównoważone budownictwo, uczciwe i przejrzyste udzielanie zamówień, usługi wodne, nanotechnologie, inteligentne systemy transportowe, zarządzanie bezpieczeństwem żywności i informatyka zdrowotna (ISO, 2012). Normy te są w większości inicjowane przez sektor pozarządowy i opracowywane przez wiele zainteresowanych stron (w tym biznes), w ścisłej współpracy z organami regulacyjnymi różnych szczebli. Nie są one obowiązkowe, ale są praktycznymi wskazówkami lub wymaganiami dla przedsiębiorstw w kontekście ich bieżących strategii (National, 2012, s. 23). W tablicy 2 podano kilka przykładów norm ISO, istotnych dla biznesu w kontekście zrównoważonego rozwoju.

W literaturze przedmiotu podkreśla się niejednokrotnie, iż im jest większy, pozytywny wpływ instytucji na rzecz wdrażania przez biznes modeli zrównoważonego rozwoju, tym wyższa jakość systemu instytucjonalnego ogółem, niezależnie od skuteczności poszczególnych indywidualnych rozwiązań instytucjonalnych (Spangenberg, 2002, s. 160). To właśnie kultura instytucjonalna danego kraju lub regionu, jakość kapitału ludzkiego, zaawansowanie technologiczne i umiędzynarodowienie przedsiębiorstw, a także kompetencje i klasa ich menedżerów, mogą być ważniejszym czynnikiem sprzyjającym wdrażaniu SDG, niż narzucane, nieakceptowane i w niewielkim stopniu wdrażalne normy i nakazy w gospodarkach rozwijających się.

Trudno wyraźnie wskazać, które z uwarunkowań instytucjonalnych mają największy wpływ na respektowanie przez przedsiębiorstwo wymogów zrównoważonego rozwoju, gdyż z jednej strony wpływają na to szczegółowe rozwiązania prawne, z drugiej zaś policy-mix instytucji na różnych szczeblach taksonomicznych, począwszy od globalnych, skończywszy na krajowych i lokalnych. Z pewnością jednak za istotne należy uznać normy ISO, wyznaczające standardy niższego zużycia zasobów i energii w celu minimalizacji szkodliwego wpływu wybranych sektorów na środowisko naturalne, jak też wpływając na wzmocnienie społecznego wymiaru strategii i działalności operacyjnej przedsiębiorstw. Ważnym celem zrównoważonego rozwoju Agendy 2030 jest także zrównoważona konsumpcja i produkcja. Jednym z celów jest m.in. ograniczenie odpadów spożywczych o połowę, poprzez działania edukacyjne oraz wdrażanie polityki w aspekcie zrównoważonych celów ekonomicznych, społecznych oraz środowiskowych. Wiele krajów wdraża założenia zrównoważonej konsumpcji realizując długoterminowe strategie środowiskowe związane z: rozwojem m.in. gospodarki o obiegu zamkniętym (GOZ), zrównoważonym rozwojem, planami na rzecz zrównoważonej konsumpcji oraz produkcji w szerokim ujęciu w działaniach strategicznych w aspekcie ochrony środowiska. W ujęciu globalnym, działania na rzecz zrównoważonej konsumpcji mają za zadanie: szanować Ziemię oraz życie w aspekcie rozwoju wszelkiej różnorodności, zabezpieczyć trwanie wspólnot oraz wdrożyć zasady zrównoważonej konsumpcji oraz produkcji, które obejmują prawa człowieka oraz zapewniają przyszłym pokoleniom zrównoważony rozwój w aspekcie społecznym, ekonomicznym oraz ekologicznym (Czaplicka-Kotas, Kulczycka, 2019, s. 195). Obecnie, na 
świecie kluczowymi działaniami na rzecz zrównoważonej konsumpcji jest edukacja oraz eko-znakowanie produktów oraz usług (na przykład w wybranych krajach UE szeroki instytucjonalny zakres wsparcia dla ograniczania niepotrzebnego spożycia i marnowania żywności) (Czaplicka-Kotas, Kulczycka, 2019, s. 195-196). Istotnymi działaniami są również dobre praktyki z zakresu zrównoważonej konsumpcji wdrażane na wszystkich szczeblach. W krajach europejskich można na przykład wymienić (Czaplicka-Kotas, Kulczycka, 2019, s. 197):

- reformę podatkową w aspekcie zrównoważonej konsumpcji - Szwecja obniżyła stawkę VAT z 25 do 12 proc. na naprawę rowerów, butów, wyrobów skórzanych i odzieży, realizując politykę zero-waste,

- umiędzynarodowienie i ujednolicenie dobrowolnego etykietowania produktów/usług, np. Nordycka Rada Ministrów wdrożyła w 5 krajach nordyckich eko-znakowanie dla 1200 produktów w 60 kategoriach, w celu zwiększenia świadomości marki wśród konsumentów,

- minimalizację odpadów z przemysłu spożywczego - 18 firm holenderskich z branży spożywczej stworzyło linię produktów Odpady sa pyszne, w której powstają produkty spożywcze z odpadów. Jednej z firm umożliwia to m.in. zminimalizowanie liczby odpadów warzywnych o 60 tys. kg rocznie.

Kolejnym przykładem bezpośredniego oddziaływania reguł instytucjonalnych na zachowania biznesowe przedsiębiorstw w kontekście zrównoważonego rozwoju, jest kwestia gospodarki cyrkularnej. Jest ona szeroko obecna w ładzie instytucjonalnym wszystkich krajów UE, sprzyjając intensywnemu rozwojowi w ostatniej dekadzie koncepcji GOZ, w którą zaangażowana jest coraz większa liczna przedsiębiorstw. Kluczowe znaczenie dla odblokowania głównych barier w dążeniu do transformacji w kierunku GOZ ma model finansowy. Na początku gospodarka taka może generować wyższe koszty, ze względu na pionierski charakter, ale zwrot z inwestycji i wydajność mogą ostatecznie okazać się wyższe (Nowaczek, Kulczycka, Pędziwiatr, 2019, s. 31).

Jednym z instrumentów polityki, które mogą wspierać dążenie do GOZ, jest system zamówień publicznych. $Z$ ich pomocą, uwzględniając założenia GOZ, samorządy mogą wywierać wpływ na rynek, a tym samym stymulować produkcję produktów i świadczenie usług zgodnych z ideą GOZ (Nowaczek, Kulczycka, Pędziwiatr, 2019, s. 31). Dodatkowymi narzędziami pozyskiwania dla miast i regionów biznesu zgodnego z koncepcjami cyrkularnymi oraz z sektora czystych technologii, ograniczającego swoje oddziaływanie na środowisko, są selektywne polityki pozyskiwania inwestorów zewnętrznych, łączenie lokalnych środowisk akademickich z lokalnymi i międzynarodowymi firmami, stymulowanie innowacji cyrkularnych w sektorach materiałochłonnych (rolnictwo, produkcja, logistyka, transport i gospodarowanie odpadami), a także wspieranie oddolnych inicjatyw społecznych dotyczących zrównoważonego rozwoju i obiegu zamkniętego, ze szczególnym uwzględnieniem biotechnologii, biochemii, genetyki i mikrobiologii (wraz z rozwojem epidemii Covid-19) (Analiza, 2020).

Ważny wpływ na strategie przedsiębiorstw związanych ze zrównoważonym rozwojem mają instytucje nieformalne. Jedną z nich jest kultura współpracy w regionalnych i lokalnych ekosystemach biznesowych. Budowa zaufania administracji lokalnej i regionalnej w relacjach z biznesem, rozwój profesjonalnej kultury biznesowej opartej na współpracy różnych interesariuszy sprawiają, iż przedsiębiorstwa są skłonne szybciej niż zazwyczaj otwierać się na nowe trendy. W takich ekosystemach opartych na współpracy i zaufaniu, szybsza i bardziej efektywna jest 
dystrybucja informacji i dobrych praktyk na temat uwarunkowań i korzyści z realizacji strategii opartej na zrównoważonym rozwoju, czy wreszcie w konsekwencji zaszczepienie w firmach określonych praktyk biznesowych, zbieżnych z SDG, które w wybranych organizacjach mogą stać się filarem nowego modelu biznesowego i innego podejścia do pracowników.

\section{Zrównoważony rozwój a własność i dostępność}

Ważnym problemem, słabo rozpoznanym w literaturze, jest kwestia roli instytucji w regulowaniu procesów przerzucania obciążeń środowiskowych i społecznych przez jedne przedsiębiorstwa na inne. Powstają pytania, na które bardzo trudno jest dać jednoznaczną odpowiedź - czy organizacje oparte jedynie na dostępie do zasobów zewnętrznych - przerzucają obciążenia środowiskowe i społeczne oraz koszty transakcyjne na inne przedsiębiorstwa i czy instytucje formalne i nieformalne ograniczają takie praktyki? Problem polega na tym, iż w organizacjach biznesowych opartych w dużym stopniu lub częściowo na dostępie do partnerów zewnętrznych (wykorzystujących modele platform), wytwarzanie towarów i usług przez partnerów, stających się następnie ofertą rynkową właściciela i organizatora platformy, podlega praktycznie tym samym regulacjom instytucjonalnym, jak pozostałych podmiotów na rynku.

Naturalnie, są wyjątki od tak sformułowanego założenia. Duża część mikro i małych firm, dostarczających ofertę do organizatorów platform i firm bazujących głównie na dostępie do zasobów, poddawana jest nie tyle niższej kontroli formalnej, lecz nieformalnej kontroli społecznej, która jest rezultatem istnienia w środowisku lokalnym bądź krajowym określonych instytucji nieformalnych. Poza tym, powyższa sieć powiązań outsourcingowych ma wielokrotnie kilka lub nawet kilkanaście pięter, zaś firmy, które dostarczają zasoby, same korzystają z usług podwykonawców, a podwykonawcy z usług kolejnych przedsiębiorstw bądź osób fizycznych. Utrudnia to diagnozę rzeczywistej skali unikania przez firmy bazujące na dostępie do zasobów oraz całkowitej sumy korzyści z tego tytułu, szczególnie w sytuacji, jeśli łańcuch wartości ma charakter międzynarodowy i jest regulowany przez mix instytucjonalny na różnych poziomach taksonomicznych.

Kolejnym problemem dla oceny konceptualnej tego zjawiska, są trudności z właściwą wyceną przez rynek aktywów środowiskowych i społecznych. Korzyści środowiskowe, takie jak wartość ekosystemów dostarczanych przez przyrodę, są praktycznie w całości wyłączone ze wspomnianej powyżej wyceny, podczas gdy wartości społeczne, takie jak czas wolny lub praca kobiet w domu, albo nie są wyceniane w ogóle w niektórych systemach społeczno-gospodarczych, albo są niedowartościowane. Prawa własności w odniesieniu do wspólnych zasobów majątkowych, takich jak zasoby wodne lub ekosystemy lądowe, a na przykład zasobów wiedzy, również nie są dobrze wycenione przez rynki (Integrating, 2015, s. 13).

Analizując potencjalne styki różnych systemów instytucjonalnych ze strategiami firm odnośnie wykorzystania zasobów, w kontekście zrównoważonego rozwoju, warto wspomnieć o normach ISO oraz o normach krajowych bezpieczeństwa żywności. Standaryzacja międzynarodowa, na przykład produkcji żywności, powoduje, iż wspomniane instytucje, niezależnie od miejsca przedsiębiorstwa w łańcuchu dostaw, są w stanie kontrolować jakość i bezpieczeństwo artykułów spożywczych, zarówno tych organizujących platformy i bazujące tylko na dostępie do zasobów, jak też tych dostarczających zasoby do platformy. Wydaje się, iż dobrym przykładem jest biznes produkcji kontraktowej, np. suplementów diety i żywności funkcjonalnej, oparty na trzech szczeblach kooperacji: organizatora platformy, który zapewnia finansowa- 
nie, nadzór i marketing, 2-3 kluczowych dostawców, których zadaniem jest projektowanie nowych cząsteczek i produktów oraz ich wytwarzanie oraz podmioty dostarczające półprodukty. $\mathrm{Na}$ każdym z tych etapów, dzięki odpowiednim regulacjom, a także nieformalnym zasadom obowiązującym w sektorze, zapewniany jest wysoki poziom bezpieczeństwa produktów i usług oraz wdrażanie wybranych wymiarów i ich składowych zrównoważonego rozwoju. Niezależnie od wymienionego przykładu, warto rozszerzyć niniejszą, bardzo wstępną a nalizę o pogłębione badania w przedsiębiorstwach.

Generalnie, optyka prezentowanego problemu wskazuje, iż dotychczas instytucje, niezależnie czy międzynarodowe czy lokalne, formalne i nieformalne, koncentrowały się i wpływają na relacje, modele biznesowe i strategie przedsiębiorstw zdecydowanie częściej przez pryzmat posiadania przez firmy zasobów, niż posiadaniu dostępów do zasobów. Ład instytucjonalny oddziałuje zatem raczej pośrednio na nowe formy organizacji wytwórczości i modele biznesowe oparte na platformach i w związku z powyższym potrzebne są nowe rozwiązania formalno-prawne w tym obszarze.

\section{Zakończenie}

$\mathrm{Na}$ podstawie prowadzonych rozważań należy stwierdzić, iż proces dostosowywania się biznesu do Agendy 2030 i wyznaczonych celów zrównoważonego rozwoju ma charakter w zdecydowanej większości adaptacyjnego przyjmowania narzuconego ładu instytucjonalnego: międzynarodowego i krajowego. Proces ten jest rozciągnięty w czasie i charakteryzuje się różną dynamiką, w zależności od stopnia rozwoju systemów społeczno-gospodarczych w poszczególnych krajach i regionach, tempa proliferacji rozwiązań prawnych i informacji o nich, standaryzacji norm międzynarodowych i prawa korporacyjnego. W dużo mniejszym stopniu wpływ na takie wybory przedsiębiorstw mają instytucje nieformalne, aczkolwiek ich znaczenie w tym procesie powoli wzrasta.

Bardzo ważnym elementem wpływającym na szybkość absorbcji przez biznes rozwiązań związanych ze zrównoważonym rozwojem, jest instytucjonalny poziom taksonomiczny. Rozwiązania te są udostępniane zazwyczaj w modelu top-down, począwszy od wymiaru globalnego i międzynarodowego, jedynie zaś w rozwiniętych ekosystemach społeczno-gospodarczych, zarówno lokalnych i regionalnych, mają miejsce równoległe procesy wdrażania rozwiązań oddolnych (bottom-up), z wykorzystaniem sieci współpracy w ekosystemie angażujących wszystkich interesariuszy. Dotychczasowe rozwiązania instytucjonalne nie nadążają za postępującą fragmentaryzacją i platformizacją biznesu.

W związku z powyższym, oddziaływanie instytucji na te procesy w kontekście zrównoważonego rozwoju odbywa się dualnie: raczej pośrednio niż za pomocą specjalnie dedykowanych, bezpośrednich rozwiązań. Rozważania prowadzone w niniejszym opracowaniu sugerują, iż niezbędne jest przeprowadzenie w najbliższej przyszłości, dla tego obszaru wiedzy, adekwatnych badań empirycznych.

\section{Bibliografia:}

Książki i rozdziały w opracowaniach zbiorowych

1. Czaplicka-Kotas A., Kulczycka J. (2019), Zrównoważona konsumpcja-przeglad dobrych praktyk krajowych i międzynarodowych, [w:] Gospodarka o obiegu zamkniętym w polityce i badaniach naukowych, Redakcja naukowa J. Kulczycka, Wydawnictwo IGSMiE: Kraków. 
2. Dovers S., River S. W. (2012), Institutions for sustainable development, Centre for Resource and Environmental Studies, The Australian National University: Canberra.

3. Mueller B., Mueller Ch. (2011), The Role of Institutions in Sustainable Development, [in:] Welfare Economics and Sustainable Development, Vol. II, Encyclopedia of Life Support Systems.

4. Nowaczek A., Kulczycka J., Pędziwiatr E. (2019), Przegląd wskaźników gospodarki o obiegu zamkniętym w dokumentach strategicznych wybranych krajów UE, [w:] Gospodarka o obiegu zamkniętym w polityce i badaniach naukowych, Redakcja naukowa J. Kulczycka, Wydawnictwo IGSMiE: Kraków.

5. Spangenberg J. H. (2002), Institutions for sustainable development: indicators for performance assessment, [in:] Governance for Sustainable Development: Barcelona.

Artykuły w czasopismach

6. Bochańczyk-Kupka D., Pęciak R. (2015), Institutions in the context of sustainable development, „The Macrotheme Review" Vol. 4(5).

7. Handmer J. W., Dovers S. R. (1996), A Typology of Resilience: Rethinking Institutions for Sustainable Development, „Organization\&Environment” Vol. 9, Issue 4.

8. Institutions as a Dimension of Sustainability, (2020), „Sustainable Development”, August.

9. Sagan M. (2016), Instytucjonalne zaangażowanie korporacji międzynarodowych a trwata przewaga konkurencyjna, „Ekonomika i Organizacja Przedsiębiorstwa” nr 11.

10. Towards Institutional Sustainability Indicators, (2019), „Sustainable Development”, December. Raporty i opracowania

11. Analiza obecnej sytuacji w zakresie przeptywów materiatowych w Lublinie, (2020), Circular Cities Program. Polska: Lublin.

12. Integrating the Three Dimentions of Sustainable Development. A framework and tools, (2015), Greening of Economic Growth Series, United Nations ESCAP.

13. National Institutions for Sustainable Development. A preliminary review of the institutional literature, (2012), United Nations Department of Economic and Social Affairs.

14. The Circular Economy. A Powerful Force for Climate Mitigation. Transformative innovation for prosperous and low carbon industry, (2020), Material Economics, Stockholm.

15. Transforming our world: the 2030 Agenda for Sustainable Development, (2015), Resolution adopted by the General Assembly on 25 September 2015.

Dr Mariusz Sagan, Instytut Rynków i Konkurencji, Kolegium Nauk o Przedsiębiorstwie SGH w Warszawie, mariusz.sagan@sgh.waw.pl, ORCID:0000-0003-3454-691X 